
hatlasjurek@gmail.com jhatlas@yahoo.pl

\title{
Gagauzi jako przykład współczesnego mikronarodu
}

Abstract: Hatłas Jerzy, Gagauzi jako przykład współczesnego mikronarodu (Gagauz People as a Micronation). „Poznańskie Studia Slawistyczne” 8. Poznań 2015. Publishing House of the Poznań Society for the Advancement of the Arts and Sciences, pp. 315-329. ISSN 2084-3011.

This article aims at givng a brief description of the Gagauz people in the areas of Bessarabia and Bulgaria. Gaugazes are a group of elusive people, whose origin seems to be obscure because of only indirect written sources. While in Bulgaria, their old country, Gagauzes maintain Bulgarian identity in addition to their own, in Bessarabia they are a distinct ethnic category. Gaugazes probably can be a micronation, by modern standards. If we consider their culture (spiritual and material), also their history and geography of settlement, they can be categorized as a Slavonic micronation. Nevertheless, their language and origins seem to be non-Slavic.

KeYwords: Gagauz people; Bulgaria; Moldova; Ukraine; Bessarabia; micronation

W ostatnich dziesięcioleciach wyraźnie nasiliły się ruchy emancypacyjne wielu grup etnicznych oraz małych narodów (tzw. mikronarodów). Powstają różnego rodzaju twory pretendujące do bycia samodzielnymi jednostkami administracyjnymi jako quasi-państwa (Kosienkowski 2008), na przykład Mołdawska Republika Naddniestrzańska (w skrócie Naddniestrze). W Polsce po przemianach ustrojowych, zgodnie z obowiązującym w RP ustawodawstwem (Ustawa o mniejszościach narodowych i etnicznych oraz o języku regionalnym, z dnia 6 stycznia 2005 roku, Dziennik Ustaw 2005 Nr 17, poz. 141), swoją odrębność mogą kultywować wszystkie mniejszości narodowe oraz etniczne. Działająca na Śląsku organizacja (Ruch Autonomii Śląska) dąży do wykreowania odrębnej narodowości śląskiej. Wspomniane procesy dotykają też innych obszarów geograficznych. Burzliwy okres rządów Michaiła Gorbaczowa w Związku Radzieckim i późniejszy upadek tego państwa-molocha, wyzwolił tendencje 
emancypacyjne wśród licznych zamieszkujących go narodów oraz grup etnicznych. Dobrym przykładem tego zjawiska są Gagauzi, którzy korzystając z okazji, całkowicie odseparowali się od Bułgarów, wyodrębnili jako oddzielny naród i stworzyli namiastkę autonomii państwowej.

\section{Dyslokacja oraz liczebność Gagauzów}

Współcześnie przeważająca część Gagauzów zamieszkuje krainę geograficzno-historyczną, jaką jest Besarabia (dwie trzecie tego obszaru znajduje się w granicach Republiki Mołdawii, a jedna trzecia należy do Ukrainy). Zasiedlają oni przede wszystkim południową jej część, która po polsku nazywana jest Budziakiem. Według współczesnego podziału geopolitycznego większość tej zbiorowości znajduje się w granicach Republiki Mołdawii, a mniejsza część w obwodzie odeskim na Ukrainie. Gagauzi żyją także w swojej dawnej ojczyźnie - Bułgarii (przede wszystkim w jej północno-wschodniej części). Wielkość populacji tej grupy pozostaje sporna. Nieoficjalne statystyki z końca lat 70 . XX wieku podawały około 40 tysięcy osób (Стаменова 2007: 7), podczas gdy oficjalne dane były niższe. Informacje z roku 1992 mówią zaledwie o około 1478 osobach (Матеева 2006: 21). Niewielkie skupiska Gagauzów istnieją w europejskiej części Turcji (tzw. Wschodnia Tracja) (Георгиев, Ангелова 2012), można ich także spotkać w północnej Grecji, Rumunii i na wielu obszarach byłego ZSRR, poza wspomnianymi już państwami: Mołdawią oraz Ukrainą (szczególnie wielu jest ich w Rosji). Oddzielna diaspora znajduje się w USA, a przede wszystkim w Brazylii, dokąd Gagauzi i Bułgarzy emigrowali za chlebem w okresie międzywojennym, nie z Bułgarii, ale właśnie z Besarabii. Dokładna liczba wszystkich Gagauzów nie jest znana. Szacunki najczęściej mieszczą się w przedziale między 200 a 250 tysięcy osób. Uściślenie danych w samej Besarabii także nie jest możliwe, ponieważ od około półwiecza normą są tam małżeństwa mieszane. Zgodnie z panującymi zwyczajami, kobieta narodowości gagauskiej, wychodząc za Bułgara, zaczyna być uważana za Bułgarkę i odwrotnie: jeśli Bułgarka ma męża Gagauza, to należy do rodziny gagauskiej. Podobny model funkcjonuje także w przypadku małżeństw mieszanych innych narodowości. Z przeprowadzonego w 2004 roku spisu ludności wynika, że w Mołdawii 
(bez Naddniestrza) mieszkało 151596 osób narodowości gagauskiej. W obwodzie odeskim na Ukrainie liczbę Gagauzów szacuje się na ponad 30 tysięcy.

\section{Etnogeneza Gagauzów}

Paradoks dotyczący Gagauzów polega na tym, że choć wypracowano wiele koncepcji ich etnogenezy, tak naprawdę nadal nie wiadomo na ten temat nic pewnego (cf. Титоров 1903: 279-289; Манов 1938; Zajączkowski 1974: 77-86; Decei 1978; Боев 1995; Гургуров 1998; Курогло 2002; Шабашов 2002: 306-657; Матеева 2006: 23-36). W nauce od dawna mówi się o Gagauzach jako o „ludzie (narodzie) nieznanego (zagadkowego) pochodzenia" (Zajączkowski 1974: 77). Według opinii badaczy bułgarskich Gagauzi są sturczonymi Bułgarami, których w czasach niewoli władze tureckie postawiły przed koniecznością wyboru: albo wyrzekną się wiary chrześcijańskiej, albo języka ojczystego i przejdą z bułgarskiego na turecki. Gagauzi mieli wtedy rzekomo wybrać prawosławie, co tłumaczyłoby używanie obecnie języka gagauskiego. Badacze, lokujący etnogenezę tej grupy w odległych dziejach, mówią o przedstawicielach języka turkijskiego żyjących na terenach zajmowanych przez wschodnich Słowian, związanych od początku z bułgarskimi terytoriami etnicznymi, takimi jak: Mezja czy Tracja (Стаменова 2007: 7). W Mołdawii oraz na Ukrainie niepodzielnie panuje opinia, że Gagauzi są potomkami średniowiecznych plemion tureckich (turkijskich). Hipoteza ta jest oficjalnie podzielana przez władze, najczęściej więc w ogóle nie dopuszcza się innych możliwości.

Poszczególne teorie dotyczące etnogenezy Gagauzów można zebrać w kilka podstawowych grup, unikając tym samym konieczności drobiazgowego ich opisywania (Hatłas 2009: 20-28). Pierwsza z nich opiera się na założeniu, że pochodzenie tego ludu jest tureckie (a ściślej turkijskie). Według tych koncepcji Gagauzi mogą być potomkami: Kumanów (Połowców), Uzów, Oguzów, Turków seldżuckich, Protobułgarów lub też mieszanką różnych plemion tureckich (turkijskich). Inni badacze (tutaj prym wiodą uczeni bułgarscy) forsują tezę, że Gagauzi to sturczeni Bułgarzy. Kolejna grupa teorii zakłada, że opisywana wspólnota nie jest ani 
słowiańska, ani turecka (turkijska), poszukuje się natomiast jej rzekomych greckich korzeni lub też zakłada, że jest ona mieszanką różnych narodowości. Reasumując: etnogeneza Gagauzów dotąd nie została jeszcze wyjaśniona, ponieważ nie dysponujemy ani jednym bezpośrednim źródłem pisanym. Nie ma nawet zgody co do wyjaśnienia etnonimu Gagauz. Fakt, że na pewnych obszarach forsuje się często tylko jedną (korzystną dla władz) teorię pochodzenia Gagauzów, ma niejednokrotnie podłoże czysto polityczne, a nie naukowe.

\section{Gagauzi w Bułgarii}

Autor niniejszego tekstu, wraz z prof. Iwanem Rusewem z Warny, odwiedził 20 czerwca 2011 roku wieś Generał Kantardżijewo (stara gagauska nazwa to Çauş küü), znajdującą się w odległości $30 \mathrm{~km}$ na północny wschód od Warny. Miejscowość ta (przez wielu Bułgarów uważana za bogatą i dobrze prosperującą) liczy około 400 stałych mieszkańców; etnicznie zdominowana jest przez Gagauzów. We wsi znajdują się budynki lokalnej administracji (kmectwo), a także cerkwi prawosławnej. Zebrany materiał daje zupełnie inny obraz lokalnej społeczności gagauskiej niż w Mołdawii czy na Ukrainie. Miejscowi Gagauzi, tak jak to miało miejsce w przeszłości, mają poczucie podwójnej tożsamości etnicznej. Czują się Gagauzami i jednocześnie Bułgarami. Znajomość języka jest już jednak dość słaba. $\mathrm{Z}$ opinii kilku respondentów wynika, że gagauskim posługuje się jeszcze tylko najstarsze pokolenie; młodzi nie znają języka swoich przodków i nie są zainteresowani uczeniem się go. Należy dodać, że język gagauski przetrwał we wsi Generał Kantardżijewo wyłącznie w formie mówionej. Wszelkie słowo pisane (nieważne, czy są to oficjalne dokumenty, czy też listy prywatne $\mathrm{w}$ formie tradycyjnej lub elektronicznej) zapisywane jest cyrylicą w wersji bułgarskiej. Każda z osób, zapytanych przeze mnie, odpowiadała po bułgarsku i prowadziła konwersację w tym właśnie języku (uważanym za ojczysty). Można zatem stwierdzić, że istnieje ogromna różnica między świadomością narodową Gagauzów (i poczuciem odrębności od Bułgarów) w Bułgarii i w Besarabii. O ile w Besarabii Gagauzi całkowicie oddzielili się od Bułgarów, o tyle w Bułgarii nadal czują się częścią narodu bułgarskiego. W przypadku tego etnosu podstawowym 
i w zasadzie jedynym kryterium odrębności od Bułgarów jest własny język; kultura materialna i duchowa jest tożsama. Język, jakim posługują się Gagauzi, należy do grupy języków turkijskich, nie jest jednak identyczny ze współczesnym językiem tureckim, używanym oficjalnie w Turcji. W Besarabii Gagauzi nazywają swój język gagauskim, natomiast w Bułgarii najczęściej określają go jako turecki i rzadziej nazywają gagauskim jako odrębnym od tureckiego (Стаменова 2007: 17). Gagauzi w Mołdawii oraz na Ukrainie są także mocno zrusyfikowani i oprócz własnego języka, powszechnie używają rosyjskiego, co stanowi już osobną kwestię.

\section{Przesiedlenia Gagauzów do Besarabii}

Gagauzi przywędrowali w międzyrzecze Dniestru i Prutu z Półwyspu Bałkańskiego w kilku falach migracyjnych, które miały miejsce od drugiej połowy XVIII do pierwszej połowy XIX wieku i związane były z wojnami rosyjsko-tureckimi (Hatłas 2012). Na czasowo okupowanych ziemiach władze carskie osadzały ludność przesiedloną z Bałkanów. Później, kiedy w roku 1812 Besarabia znalazła się w granicach Rosji, na szeroką skalę ściągano tam osadników, którzy z czasem otrzymali status kolonistów. Największą grupę wśród ludności bałkańskiej stanowili Bułgarzy oraz Gagauzi. Tych ostatnich miejscowe władze przez długi czas nie odróżniały od Bułgarów, co najwyżej wspominano o Bułgarach mówiących po turecku. Zdaniem władz rosyjskich, oba etnosy idealnie nadawały się do zagospodarowywania pustych stepów Budziaku, z których deportowano Tatarów nogajskich. Była to ludność prawosławna (czyli wyznania identycznego, jakie oficjalnie panowało w Rosji) i nastawiona prorosyjsko. Migracje te miały w ogromnej większości charakter dobrowolny. Władze rosyjskie prowadziły szeroko pojętą akcję agitacyjną, obiecując przybyszom status kolonistów oraz bezpieczne i dostatnie życie. Dopiero na miejscu nierzadko okazywało się, że obietnice różnią się od rzeczywistości, co z kolei powodowało ruchy migracyjne w odwrotną stronę i to na dużą skalę (o czym w literaturze rosyjskojęzycznej najczęściej się w ogóle nie wspomina). Uciekano na ziemie rdzennie bułgarskie, ale robili to przede wszystkim Bułgarzy. Po protestach przesiedleńców władze carskie przyznały osadnikom status kolonistów, zwalniając ich (czasowo 
lub bezterminowo) z płacenia podatków oraz z niektórych uciążliwych obowiązków (na przykład ze służby wojskowej). Mieli oni jednak obowiązek świadczenia usług na rzecz armii, takich jak udzielanie kwater oraz zapewnianie transportu. Paradoksalnie, o ile Bułgarzy w swojej zasadniczej masie pozostali na Półwyspie Bałkańskim, a w Besarabii stworzyli największą diasporę, o tyle w przypadku Gagauzów sytuacja była odwrotna. Do Besarabii przesiedliła się większość, a na miejscu pozostała tylko niewielka grupa. Gagauzi stworzyli w Budziaku nowe terytorium zwartego osadnictwa, które wszędzie przeplatało się z osadnictwem bułgarskim. Etnosy te zamieszkiwały albo w sąsiednich miejscowościach, albo wręcz w tych samych (jak choćby duże wsie Kirsowo w Mołdawii oraz Kubej obecnie Czerwenoarmejskoje - na Ukrainie). Taki stan rzeczy przetrwał do czasów współczesnych.

W ciągu swej dwustuletniej obecności w Besarabii Gagauzi wielokrotnie zmieniali przynależność państwową. Początkowo Budziak znajdował się w granicach Turcji, później (od roku 1812) była tam Rosja. W okresie międzywojennym cała Besarabia należała do Rumunii. Czasy rumuńskie opisywane są w historiografii radzieckiej i postradzieckiej skrajnie tendencyjnie: Rumunię oskarża się nieomal o wszystko, co złe, podczas gdy Rosję oraz władze radzieckie wyraźnie się gloryfikuje. Nie wiąże się pewnych faktów, jak chociażby tego, że to właśnie na czasy rumuńskie przypada działalność Michaiła Czakira, duchownego, historyka, tłumacza, intelektualisty oraz duchowego przywódcy Gagauzów (Мошин, Копущу 2013). To właśnie Michaił Czakir (uznawany powszechnie za największego gagauskiego bohatera narodowego) napisał pierwszą historię Gagauzów (nowe wydanie: Чакир 2005), w czym władze rumuńskie nie dość, że mu nie przeszkadzały, to jeszcze wspomagały tę inicjatywę finansowo. Rumuni w okresie międzywojennym oddzielili Gagauzów od Bułgarów w oficjalnych spisach ludności, sprowadzano wówczas także nauczycieli z Turcji. Dopiero pod koniec okresu międzywojennego polityka władz rumuńskich wobec mniejszości narodowych stała się otwarcie wroga, przy czym można mówić o polityce świadomego szantażu w stosunku do nich, ale w żadnym przypadku nie o stosowaniu eksterminacji.

W roku 1940 po ultimatum radzieckim Besarabię zajęła Armia Czerwona. Wydarzenia te jeszcze dziś rosyjskojęzyczni i postradzieccy badacze próbują przedstawiać jako wyzwolenie spod znienawidzonego jarzma 
rumuńskiej okupacji. W rezultacie jeden reżim został zastąpiony drugim, w mojej ocenie: znacznie gorszym. Zaraz po utworzeniu władzy radzieckiej przystapiono do procesu kolektywizacji rolnictwa. Bogatych rolników (tzw. kułaków) oraz miejscową inteligencję (zwłaszcza bułgarską) poddawano represjom. W roku 1941 do Besarabii powrócili Rumuni, a w roku 1944 znów została ona zajęta przez Armię Czerwoną. W latach 1946-1947 w Budziaku zapanował straszny głód. Susza, która na tym terytorium jest zjawiskiem cyklicznym i normalnym, została najwyraźniej wykorzystana politycznie w celu rozprawienia się z niepokornymi rolnikami, którzy nie chcieli kolektywizacji. W wyniku braku żywności oraz nałożenia przez państwo radzieckie drakońskich norm, z głodu zmarło w poszczególnych miejscowościach od $20 \%$ aż do $60 \%$ mieszkańców. Umierali przedstawiciele wszystkich narodowości zamieszkujących Budziak, ponieważ jednak Gagauzi byli niemal wyłącznie rolnikami, ponieśli największe straty demograficzne. Obecnie o wydarzeniach tych mówi się i pisze otwarcie (Курдогло 2010), a w wielu miejscach zamieszkałych przez Gagauzów powstały skromne pomniki poświęcone tej zbrodni ludobójstwa (na przykład w miejsowościach: Beszalma w Mołdawii czy też Kotłowina oraz Winogradowka na Ukrainie). Te tragiczne wydarzenia do dziś są dla starszego pokolenia Gagauzów tak traumatyczne, że wielu boi się o nich mówić. We wsi Winogradowka (Kurczu) pewna starsza kobieta mieszkająca tuż obok cmentarza, zapytana przeze mnie oraz pewną miejscową osobę o głód w latach 1946-1947, najwyraźniej panicznie bała się rozmawiać o tamtych wydarzeniach. Zasłaniała się podeszłym wiekiem i związaną z tym utratą pamięci. Odmówiła też podania swojego imienia i nazwiska oraz narodowości, szybko zakończyła rozmowę i wycofała się do swojego domu (wydarzenie to miało miejsce w 26 października 2008 roku - Winogradowka [Kurczu], ul. Jordana Bajeva nr 21).

\section{Republika Gagauska oraz Terytorium Autonomiczne Gagauzja}

Na fali odwilży w ZSRR w lutym 1988 roku powstał w Komracie klub dyskusyjny pod nazwą Gagauz-halkı, który niebawem przerodził się w poważną siłę polityczną stworzoną przez Gagauzów. W roku 1990 
powołano do życia separatystyczną Republikę Gagauską (Кендигелян 2009). Obejmowała ona terytoria zdominowane przez ludność gagauską na południu Mołdawii. Władze centralne w Kiszyniowie nie uznały tego quasi-państwowego tworu i szykowały się do rozwiązania siłowego. Dopiero 23 grudnia 1994 roku doprowadzono do kompromisu. Gagauzi zgodzili się odstąpić od secesji w zamian za stworzenie uznanej przez Kiszyniów autonomii. Otrzymała ona oficjalną nazwę Terytorium Autonomiczne Gagauzja (Gagauz Yeri) (Ангели 2006). Stworzono zatem dla Gagauzów namiastkę ich państwowości. Utworzono nowe szczeble miejscowych władz: na czele autonomii stanął gubernator, mający tytuł baszkana, powstał także lokalny parlament oraz miejscowy rząd (komitet wykonawczy). Terytorium Gagauzji jest niewielkie, obejmuje $1832 \mathrm{~km}^{2}$, nie stanowi też zwartej przestrzeni: są to cztery enklawy leżące w południowej Mołdawii. Największa z nich obejmuje miasta Komrat oraz Czadyr Lunga z podlegającymi im administracyjnie okolicznymi miejscowościami. Druga znajduje się na południu (miasto Wulkaneszty i okoliczne wsie). Pozostałe dwie enklawy to wsie Kopczak oraz Karbalia.

Na Ukrainie (w obwodzie odeskim) Gagauzi nie zdołali wywalczyć sobie żadnych specjalnych praw. Znajduje się tam kilka dużych miejscowości zdominowanych przez ten etnos: Alaksandrowka, Dimitrowka, Czerwenoarmejskoje (tutaj połowę mieszkańców stanowią Bułgarzy), Kotłowina oraz Stare Trojany. Granica państwowa po upadku ZSRR podzieliła zatem obszar zwartego osadnictwa gagausko-bułgarskiego w Budziaku w sposób sztuczny i nieprzemyślany, zostawiając jedne miejscowości po mołdawskiej stronie granicy, a drugie po ukraińskiej.

\section{Krótka charakterystyka Gagauzów w Besarabii}

Podstawowym markerem odrębności Gagauzów od Bułgarów w Besarabii jest język, który nazywają gagauskim. Szeroko o Gagauzach pisał rosyjski uczony i oficer Walentin Moszkow (nowe wydanie - Мошков 2004). W Polsce literatura na ten temat nie jest jeszcze zbyt obfita (cf. Kosienkowski 2007; Hatłas 2009, 2011; Lipiński 2014). Na obszarze Terytorium Autonomicznego Gagauzja język gagauski jest uznany za oficjalny, obok rosyjskiego oraz mołdawskiego/rumuńskiego. O ile jednak 
mołdawskiego (rumuńskiego) nie słyszy się niemalże nigdzie i próżno jest szukać napisów w tym języku (poza niektórymi tylko szyldami na budynkach instytucji państwowych, na pocztach czy szkołach), o tyle rosyjskim posługują się wszyscy. Często można usłyszeć także mieszaninę gagauskiego i rosyjskiego. Niektórzy badacze bułgarscy postrzegają przyznanie przez władze odrębnego statusu językowi gagauskiemu jako radziecką mistyfikację mającą na celu sztuczne oddzielenie Gagauzów od Bułgarów (Балкански, Кондов 2012: 102-103).

Mieszkańcy Gagauzji ubierają się na wzór europejski, więc strój nie stanowi obecnie żadnego wyznacznika odrębności Gagauzów w stosunku do innych mieszkańców Besarabii (jedynie miejscowe zespoły ludowe pieczołowicie kultywują stare tradycje - stroje ludowe, pieśni i tańce a na wsiach istnieje jeszcze bogaty folklor związany z tradycyjną obrzędowością kalendarzową). Podobnie wygląda sprawa $\mathrm{z}$ budownictwem. Tradycyjne stare gagauskie domy mieszkalne nie odróżniają się niczym od tych, w których mieszkają ich sąsiedzi innych narodowości. O ile zatem można mówić w Besarabii o domu besarabskim (w sensie terytorialnym i architektonicznym), o tyle z całą pewnością nie istnieje dom gagauski.

Pod względem wyznania Gagauzi w większości związani są z prawosławiem. Po latach ateizacji widać wyraźne odrodzenie religijne. Zamknięte w czasach komunistycznych świątynie zostały wyremontowane i otwarte dla wiernych. W czasach radzieckich na terytorium Gagauzji pozostały czynne zaledwie dwa budynki cerkwi prawosławnej (w miejscowościach Kongaz oraz Czok Majdan). Tam, gdzie obiekty sakralne zostały zniszczone lub gdzie nie było ich w przeszłości, wybudowano nowe. Obecnie cerkwie prawosławne znajdują się w prawie wszystkich miejscowościach należących do Gaguzji. W ostatnich latach nastał jednak na tym obszarze wyraźny pluralizm religijny, związany z ekspansją wielu odłamów protestantyzmu. Niemalże w każdej gagauskiej miejscowości, oprócz budynku cerkwi prawosławnej, istnieje przynajmniej jeszcze jedna świątynia innego wyznania. Religijność mieszkańców bywa często powierzchowna i tradycyjna, w myśl zasady, że Gagauz to człowiek prawosławny (,skoro dziadkowie i rodzice byli prawosławni, to ja też jestem prawosławny/prawosławna”), co nie zawsze przekłada się na rzeczywiste przekonania religijne danej osoby.

W pewnej formie przetrwała też do dziś tradycyjna kuchnia gagauska (Никогло 2004). O ile w restauracjach i barach trudno spotkać prawdziwie 
gagauskie potrawy, o tyle w warunkach domowych są one niejednokrotnie przygotowywane.

Władze Gagauzji zabiegają o integrację z diasporą. W tym celu w stolicy Gagauzji Komracie odbyły się już trzy światowe kongresy Gagauzów. Ostatni z nich miał miejsce jesienią 2012 roku. Uczestniczyłem w drugim oraz trzecim kongresie na zaproszenie baszkana Gagauzji Michaiła Formuzała.

\section{Gagauzi i Bułgarzy oraz Gagauzi i Rosjanie - związki wzajemne}

O relacjach Gagauzów z Bułgarami, stereotypach i uprzedzeniach, pisał już Walentin Moszkow. Wynika z nich, że Gagauzi w przeszłości nie mieli najlepszej opinii о Bułgarach (Мошков 1901: 35). Jeśli mieszkali w tej samej miejscowości (na przykład w Kirsowie), to tworzyli odrębną enklawę, do której Bułgarzy nie mieli wstępu. Nie zawierano małżeństw mieszanych, a w miejscowej cerkwi w Kirsowie podczas liturgii obie wspólnoty zajmowały odrębne części świątyni. O pewnym zadawnionym konflikcie w tej miejscowości pisał Jarosław Derlicki (Derlicki 2012), a o stereotypach związanych ze wzajemnym negatywnym postrzeganiem się Gagauzów i Bułgarów oraz o ich „szorstkiej przyjaźni” świadczą badania przeprowadzone w obwodzie odeskim na Ukrainie (Kłos 2014).

Nie należy jednak eksponować tych stereotypów i wzajemnej niechęci gagausko-bułgarskiej, gdyż są one już tylko echem dawno minionych czasów. Mimo różnych informacji, świadczących o rzekomo negatywnym nastawieniu i zadawnionym antagonizmie między Gagauzami a Bułgarami, widać także współpracę i dobrosąsiedzkie kontakty. Deklaracje są mniej istotne niż to, jak postępuje się w stosunku do sąsiadów w sytuacjach krytycznych. W czasach radzieckich szkoła oraz wspólna praca zawodowa przedstawicieli obu etnosów doprowadziła do zniwelowania rozmaitych uprzedzeń. Pojawiły się małżeństwa gagausko-bułgarskie, które obecnie są w Budziaku rzeczą normalną. Niechęć zastąpiła współpraca i wzajemna pomoc. Na przykład kiedy Gagauzja próbowała wywalczyć swą odrębność od reszty Mołdawii, zaproponowano powołanie Republiki Budziackiej, która objęłaby terytoria zamieszkiwane przez Gagauzów 
i Bułgarów zarówno w południowej Mołdawii, jak i w obwodzie odeskim, należącym do Ukrainy. Do tej idei powracano jeszcze później. Mieszkańcy niektórych bułgarskich miejscowości w dramatyczny sposób, kładąc się na szosie, zatrzymywali pochód interwentów (tzw. ochotników), którzy dążyli do konfrontacji siłowej z Gagauzami, przejawiającymi tendencje niepodległościowe. Duża wieś, a od niedawna miasto Twardica, która jako enklawa należy administracyjnie do rejonu taraklijskiego, nieraz wyrażała wolę przyłączenia się do Gagauzji. Swoją chęć mieszkańcy motywowali względami praktycznymi: argumentowano, że z Twardicy do lekarza do Czadyr Lungi w Gagauzji jest zaledwie 12 kilometrów, natomiast do Tarakliji aż 40. Obecne władze rejonu taraklijskiego oraz primar (mer) miasta Taraklija Sergej Filipow bardzo energicznie opowiadają się za współpracą z Gagauzją i za natychmiastową integracją z Rosją, a przeciw Unii Europejskiej. Poparli referendum gagauskie z 2 lutego 2014 roku, które przez władze kiszyniowskie zostało uznane za niekonstytucyjne i niemające jakichkolwiek skutków prawnych.

W odróżnieniu od Gagauzów w Bułgarii, Gagauzi w Besarabii w swoich zapatrywaniach i przekonaniach politycznych są mocno zorientowani na Rosję. Panuje powszechna nostalgia za ZSRR i czasami radzieckimi. Często postawa ta jest bezkrytyczna i prowadzi do zaślepienia: głoszenie poglądów innych niż promoskiewskie nie jest mile widziane, przy czym nierzadko starsze osoby, gloryfikujące czasy radzieckie, deklarują jednocześnie, że są głęboko wierzące, co stanowi sprzeczność wobec komunistycznej polityki wyznaniowej. Pewien znany mi dobrze i zaprzyjaźniony dziennikarz gagauski z Komratu w korespondencji mailowej w roku 2014 twierdził, że „Stalin był geniuszem i wcieleniem wszelkiego dobra” (mimo że jego dziadkowie zostali zesłani do łagru na Syberii), a aneksja Krymu przez Federację Rosyjską i otwarta wojna ukraińsko-rosyjska w Donbasie to walka wyzwoleńcza uciśnionych rosyjskojęzycznych obywateli przeciwko okrutnym banderowcom. Z takimi poglądami trudno dyskutować. Władze kiszyniowskie oskarżane są o złe intencje, a Rumunia tradycyjnie o wszystko, co najgorsze (to niewątpliwie relikt propagandy radzieckiej). O zbrodni ludobójstwa, którą było wywołanie sztucznego głodu w latach 1946-1947, osoby te zdają się zapominać, podkreślając jednocześnie, że „był wtedy porządek, była dla wszystkich praca, żyło się dobrze i sielsko". Radzieckie nazwy ulic w całej Gagauzji zachowano; 
próżno szukać gdziekolwiek ulicy Michaiła Czakira, ale prawie w każdej miejscowości główna ulica nadal nosi imię Lenina. Jego pomniki stoją w wielu miejscowościach, w stołecznym Komracie, a także przed budynkiem władz autonomii.

Co ciekawe, w pewnym sensie język rosyjski towarzyszy Gagauzom w Besarabii także i pośmiertnie: mimo że gagauski już dawno zmienił swój alfabet na łaciński (oficjalnie w Mołdawii), to napisy na grobach zmarłych wykonane są wyłącznie cyrylicą, w języku rosyjskim, z podaniem otczestwa.

\section{Zakończenie}

Gagauzi przeszli długą drogę do emancypacji, która zakończyła się sukcesem jedynie na ziemiach położonych między Prutem a Dniestrem. Splot wielu okoliczności sprawił, że społeczność ta ma wyraźne poczucie odrębności od sąsiadów (Mołdawian, Ukraińców, Rosjan, a zwłaszcza od Bułgarów). Pierwszy krok uczynili Rumuni, separując administracyjnie Gagauzów od Bułgarów. Później władze radzieckie uznały gagauski za odrębny język i nawet na krótko wprowadziły go do szkół (w miejscach zwartego osadnictwa gagauskiego). Z czasem świadomość odrębności przybrała formę jawnego i świadomego separatyzmu od etnosu bułgarskiego. Współcześnie Gagauzi w Besarabii określają się jako odrębny naród lub przynajmniej jako osobny lud. Oba te pojęcia są nieostre: w języku tureckim bowiem słowo halk oznacza zarówno 'naród', 'narodowość', 'nację', jak i 'lud', 'ludność', 'mieszkańców', 'ludzi'. W gagauskim jest identycznie. Na język rumuński halk tłumaczy się jako popor, czyli może to być także zarówno 'naród', jak i 'lud'. Spore zamieszanie wprowadza z kolei tłumaczenie terminu halk na język rosyjski jako народ. Dochodzi bowiem w tym przypadku do zniekształcenia jego znaczenia, ponieważ słowo to oznacza w rosyjskim przede wszystkim 'lud', a znacznie rzadziej 'naród'. Nieważne jednak, jakiego użyjemy tłumaczenia, Gagauzi w Besarabii jasno i wyraźnie określają się współcześnie jako niezależny naród lub przynajmniej odrębna grupa etniczna (bezpieczniej może w tym przypadku użyć terminu etnos). Z kolei w Bułgarii, jak też na wszelkich innych terenach, na których żyją Gagauzi, pozostała tradycyjna podwójna samoidentyfikacja: 
„jesteśmy Gagauzami, ale także Bułgarami”. Gagauzi w pełni zasługują na zaliczenie ich w poczet współczesnych mikronarodów. Brak jakichkolwiek bezpośrednich źródeł pisanych pozostawia kwestię etnogenezy Gagauzów wyłącznie w sferze hipotez. Nie można zatem stwierdzić, że są Słowianami lub też, że nimi nie są, bo takie podejście wykluczałoby bezstronność. Większość badaczy wiąże Gagauzów z szeroko rozumianym światem turkijskim (niezależnie, czy za ich przodków uważa się średniowieczne plemiona tureckie [turkijskie], czy zakłada pochodzenie wprost od Turków). Z kolei władze bułgarskie traktują Gagauzów jako nieodłączny komponent narodu bułgarskiego. Podobnie jak Bułgarzy z Besarabii mogą starać się o paszport bułgarski i o obywatelstwo bułgarskie (i często to robią). Nie brakuje stwierdzeń, w myśl których „Gagauzi są społecznością nierozerwalnie związaną z etnokulturową historią etnosu bułgarskiego" (Матеева 2006: 16). Stoję na stanowisku, że skoro sami Gagauzi w Besarabii identyfikują siebie w kategoriach odrębnego etnosu, to należy to uszanować. Jednak bardzo długie zamieszkiwanie Gagauzów oraz Bułgarów obok siebie lub też razem w tych samych miejscowościach doprowadziło do unifikacji ich kultur. Jedynym wyznacznikiem odrębności pozostał język. Nie da się pisać historii tych samych miejscowości, zamieszkałych przez oba etnosy, oddzielnie dla Gagauzów i dla Bułgarów. Sądzę, że Gagauzów można także zaliczyć „technicznie” do grona „mikronarodów słowiańskich”, jasno jednak deklarując, że za podstawowe kryterium bierzemy w tym przypadku kulturę materialną oraz duchową, a także wspólną historię i terytorium (zarówno w Bułgarii, jak i w Besarabii) i niewyjaśnioną etnogenezę, a nie tylko ich własny odrębny język ojczysty i rzekome pochodzenie turkijskie, które nie zostało w nauce poparte jakimkolwiek bezpośrednim źródłem pisanym. Nie należy także zapominać o podwójnej samoidentyfikacji Gagauzów w samej Bułgarii oraz na niektórych innych terenach.

Literatura dotycząca Gagauzów jest już obfita (cf. Zajączkowski 1956; 1966; Măcriş 2000; 2003; 2008; Nasrattinoğlu 2009; Zanet 2010), choć jej wartość merytoryczna bywa różna. O ile prace poświęcone etnologii, wydane na obszarze postradzieckim, są z reguły obiektywne, o tyle nie da się tego powiedzieć o tekstach historycznych (przede wszystkim rosyjskojęzycznych), które wciąż jeszcze niejednokrotnie powielają radziecką propagandę. Dla przeciwwagi warto zatem sięgnąć także po literaturę rumuńską (na przykład: Scurtu 2003). 


\section{Literatura}

Decei A., 1978, Problema colonizării turcilor selgiucizi în Dobrogea secolului al. XIIIlea, w: idem, Relaţii româno-orientale. Culegere de studii, Bucureşti, s. 169-192.

Derlicki J., 2012, Zmierzch konfliktu czy jego ukryte trwanie? Butgarsko-gagauska wieś Kirsowo, w: Między etnicznościa a lokalnościq. Pogranicze bułgarsko-gagauskie w Besarabii, red. J. Derlicki, Warszawa, s. 53-65.

Hatłas J., 2009, Gagauzja i Gagauzi. Historia oraz wspótczesność, Poznań.

Hatłas J., 2011, The Gagauz People in Bessarabia, „Słupskie Studia Historyczne” nr 17, s. 191-199.

Hatłas J., 2012, Przesiedlenia ludnościowe z Pótwyspu Bałkańskiego do Besarabii w XVIII i XIX wieku oraz kwestia etnogenezy Gaguzów, w: Między etnicznościa a lokalnościq. Pogranicze bułgarsko-gagauskie w Besarabii, red. J. Derlicki, Warszawa, s. 11-24.

Kłos M., 2014, O szorstkiej przyjaźni dwóch narodów. Analiza relacji bułgarsko-gagauskich w Budziaku, w: Bałkany na Ukrainie. Bułgarzy, Gagauzi i Albańczycy z ukraińskiego Budziaku, red. W. Lipiński, Warszawa, s. 153-166.

Kosienkowski M., 2007, Geneza, status i funkcjonowanie terytorium autonomicznego Gagauzja, „Stosunki Międzynarodowe” t. 36, nr 3-4, s. 205-217.

Kosienkowski M., 2008, Quasi-państwo w stosunkach międzynarodowych, „Stosunki Międzynarodowe" t. 38, nr 3-4, s. 151-162.

Lipiński W. (red.), 2014, Bałkany na Ukrainie. Butgarzy, Gagauzi i Albańczycy z ukraińskiego Budziaku, Warszawa.

Măcriş A., 2000, Găgăuzii şi Românii. Însemnări, Bucureşti.

Măcriş A., 2003, Găgăuzii din Basarabia în trecut şi în prezent, Bucureşti.

Măcriș A., 2008, Găgăuzii, București.

Nasrattinoğlu İ.Ü., 2009, Moldova ve Gagauzya, Ankara.

Scurtu I. (red.), 2003, Istoria Basarabiei de la începuturi până în 2003, Bucureşti.

Zajączkowski W., 1956, Przyczynki do etnografii Gagauzów, „Rocznik Orientalistyczny" t. 20, s. 353-360.

Zajączkowski W., 1966, Język i folklor Gagauzów z Bułgarii, Kraków.

Zajączkowski W., 1974, К этногенезу гагаузов, „Folia Orientalia” nr 15, s. 77-86.

Zanet T., 2010, Gagauzluk: Kultura, ruh, adetlär, Chişinău.

Ангели Ф., 2006, Гагаузская Автономия. Люди и факты (1989-2005 гг.), Кишинев.

Балкански Т, Кондов В., 2012, Бесарабски бележник, Велико Търново.

Боев Е., 1995, Не заблудата а лъжата за гагаузите, София.

Георгиев Г., Ангелова Д., 2012, Етнокълтурна памет и идентичност у гагаузите от Източна Тракия през XX в., w: Българите в Северното Причерноморие. Изследвания и материали, t. 11, Одеса-Велико Тьрново, s. 185-229.

Гургуров Д., 1998, Гагаузы - потомки тюрок-огузов или славяно-болгар?, Кишинев. 
Кендигелян М., 2009, Гагаузская Республика. Борьба гагаузов за национальное самоопределене. 1989-1995. Воспоминания. Документы, Комрат.

Курдогло К., 2010, Голод в Гагаузии (1946-1947 г2.), Комрат-Кишинев.

Курогло С.C (red.), 2002, Етногенез и этническая история гагаузов. Материаль и исследования посвяшченные 150-летию В. Мошкова, Кишинев-Етулия.

Манов А., 1938, Потеклото на гагаузите и техните обичаи и нрави, t. 1-2, Варна. Матеева В., 2006, Гагаузите - още един поглед, София.

Мошин О., Копущу В., 2013, Протойерей Михаил Чакир: служние Богуи ближним. К 75-летию sо дня кончины протореиея Михаила Чакира, Кишинев.

Мошков В.А., 1901, Гагаузы Бендерского уезда, „Этнографическое обозорение” t. 49 , nr 2, s. 29-49.

Мошков В.А., 2004, Гагаузы Бендерского уезда (Этнографические очерки и материаль), Кишинев.

Никогло Д., 2004, Система питания гагаузов в XIX-начале XX вв, Chişinău.

Стаменова Ж. (red.), 2007, Гагаузите в България. Записки от терена, София.

Титоров И., 1903, Българите в Бесарабия, София.

Шабашов А., 2002, Гагаузы: система терминов родства и происхождение народа, Одесса.

Чакир М., 2005, История гагаузов Бессарабии, w: Страницы истории и литературы гагаузов XIX-нач. ХХ вв., red. С.С. Булгар, Кишинэу, s. 80-108. 
